Submitted $9^{\text {th }}$ October 2020

Accepted $2^{\text {th }}$ June 2021

\title{
REVITALIZING LOCAL ECONOMY THROUGH VILLAGE TOURISM: CASE STUDY OF DUSUN GOJANG UTARA, SELAYAR ISLANDS, SOUTH SULAWESI, INDONESIA
}

\author{
Asep S. Adhikerana ${ }^{1 *}$, Nasruddin ${ }^{2}$, Sultandar Zulkarnaen ${ }^{3}$, Herman S. \\ Simandjuntak $^{4}$, Jito Sugardjito ${ }^{5}$, Andi Rismayani ${ }^{6}$ \\ ${ }^{1,4,5}$ Centre for Sustainable Energy and Resources Management, Universitas Nasional, \\ Indonesia. \\ ${ }^{2}$ Bidang Litbang dan Pengendalian Pembangunan (Bappelitbangda), Kabupaten \\ Kepulauan Selayar, Indonesia \\ ${ }^{3}$ Dinas Kepariwisataan Kabupaten Kepuluan Selayar, Indonesia \\ ${ }^{6}$ CSREM-UNAS field assistant, Benteng, Selayar, Indonesia \\ asepadhikerana@gmail.com
}

\begin{abstract}
The study was done in March 2020 in Dusun Gojang Utara, Bontomarannu Village, Bontomanai Sub-district, Selayar Islands District, aiming at exploring the opportunity and feasibility of "Kenari Forest" as a tourist attraction. A descriptive-status approach was used in this study that was sought to answer questions about real-life situations, and in addition, the scoring of potential tourism object/attraction utilized the 2003 ADO-ODTWA Guideline. Overall, Dusun Gojang Utara has a high potency as a community-based tourism destination, although there are four criteria needed improvement, namely: accessibility, surrounding conditions, management and services, and climate. Unfortunately, Dusun Gojang Utara as a tourist village is yet to be the priority of the local government,. Indeed, as part of the Bontomarannu Village, this dusun is included as an agro-tourism development area, but the potential of this dusun is not for agro-tourism, instead its tourism attraction resides in the local livelihood itself.
\end{abstract}

Keywords: community-based tourism; village tourism; canary nuts

\section{INTRODUCTION}

The tourism sector has an important role as a source of national foreign exchange, as well as encouraging national economic growth, particularly in reducing unemployment and increasing national productivity. In her analysis, Yakup (2019) found that tourism has a positive and significant effect on economic growth in Indonesia. The contribution of tourism sector to the Indonesia's GDP was $5.47 \%$ in 2015, and 5.82\% in 2016 (LPEM-FEBUI, 2018). Since 2010, however, global tourism has undergone a shift from mass tourism to responsible tourism. Unfortunately, Indonesia has not addressed such a change seriously due to lack of knowledge about the global change in tourism paradigm (Poerwanto, 2020). One of responsible tourism types is known as rural (or village) tourism. 
In its true sense, rural tourism appeared in the late 19th century, and advanced enthusiastically after the World War II (Tang, 2017). In their study in five eastern German rural regions, Neumeier \& Pollermann (2014) found that tourism can function as a vehicle for rural development despite the facts that those regions are not not suitable for tourism. Rural tourism has also developed vigorously in Asian countries, such as India, Nepal, and Thailand. Despite the facts that: (a) popular tourism attractions in Bali reside mostly in villages, (b) there are success stories about community-based rural tourisms in Yogyakarta (Purbasari \& Asnawi, 2014), and (c) so many recommendation on how to develop green village tourism have been put forward, (KKUKM, 2015; Salmiah, 2019; Sekartjakrarini, Bernanto, Laksana, \& Wahyudi, 2015; Sjamsu \& Dahrma, 2018), the development of rural tourism has long been ignored in Indonesia. Having realized that rural tourism could be more resilient that mass tourism, the GoI started to promote "village tourim" through Nusantara Village Tourism Festival in 2019 (Suyono, 2019).

Programs to develop tourism have also been formulated and implemented in South Sulawesi, and there has been a steady increase in the number of visitation to this region (see Table 1). But the visits have been mainly to Makassar City, and only fractions to other destinations in the region (Ferdiansyah, 2019). In 2018, the Provincial Government of South Sulawesi has set up 12 programs for tourism development, namely: capacity building (the agency office) (3 programs), cultural tourism (4 programs), capacity building (creative local economy) ( 2 programs), tourism marketing (1 program), development of tourism destination (1 program), and development of partnership (1 program) - altogether there are 129 activities (Disbudpar-Sulsel 2018). Only three of those activities are related to "rural tourism", which are directed to the existing rural tourism destinations. Developing a newly alternative tourism based on local community's livelihood does not seem to be the priority.

Table 8. The number of visitation to South Sulawesi during the period of 2016-2018

\begin{tabular}{|l|l|l|l|l|}
\hline No. & Number of visitation & $\mathbf{2 0 1 6}$ & $\mathbf{2 0 1 7}$ & $\mathbf{2 0 1 8}$ \\
\hline 1. & Foreign tourists & 175,000 & 185,000 & 200,000 \\
\hline 2. & National and domestic tourists & $5,750,000$ & $6,000,000$ & $6,250,000$ \\
\hline
\end{tabular}

Source: Division of Tourism Industry and Destination Development of South Sulawesi 2018 (Bidang Pengembangan Destinasi dan Industri Pariwisata Sulawesi Selatan 2018), cited from Ferdiansyah (2019).

Tourist attractions in the Selayar Islands, which are currently in great demand, still rely on the beauty of beaches and coral reefs. And indeed, the beauty of the coral reefs of Taka Bonerate National Park has become an icon of South Sulawesi (Ferdiansyah, 2019). A number of existing tourism businesses in Selayar Island, both managed by foreign and local entrepreneurs, combine the two tourist objects. The Government of Selayar Islands District is very aggressively promoting the region's potential as a tourist destination, both natural and cultural tourisms, with a desire that Selayar Islands could be established as a Special Economic Zone for Tourism. At the same time, the district government seeks to develop other potential locations or tourism objects, and one of its is "Kenari (canarium nut) Forest". In 
November 2018 (Balai Taman Nasional Taka Bonerate, 2018), the district government team conducted a location survey and discussion on the development of the "Kenari Forest" ecotourism, but the conclusions did not indicate the direction of development. This study seeks to explore the opportunity and feasibility of "Kenari Forest" as a tourist attraction.

\section{METHODOLOGY}

The study was done in March 2020 in Dusun Gojang Utara, Bontomarannu Village, Bontomanai Sub-district, Selayar Islands District (see Figure 1). A descriptive-status approach was used in this study that was sought to answer questions about real-life situations. Studies on the development of communitybased tourism have been done in Indonesia, particularly in Jawa, Bali and Lombok, but it has rarely been investigated from South Sulawesi, especially Selayar Island. Hence, this study should contribute to the science of community-based tourism.

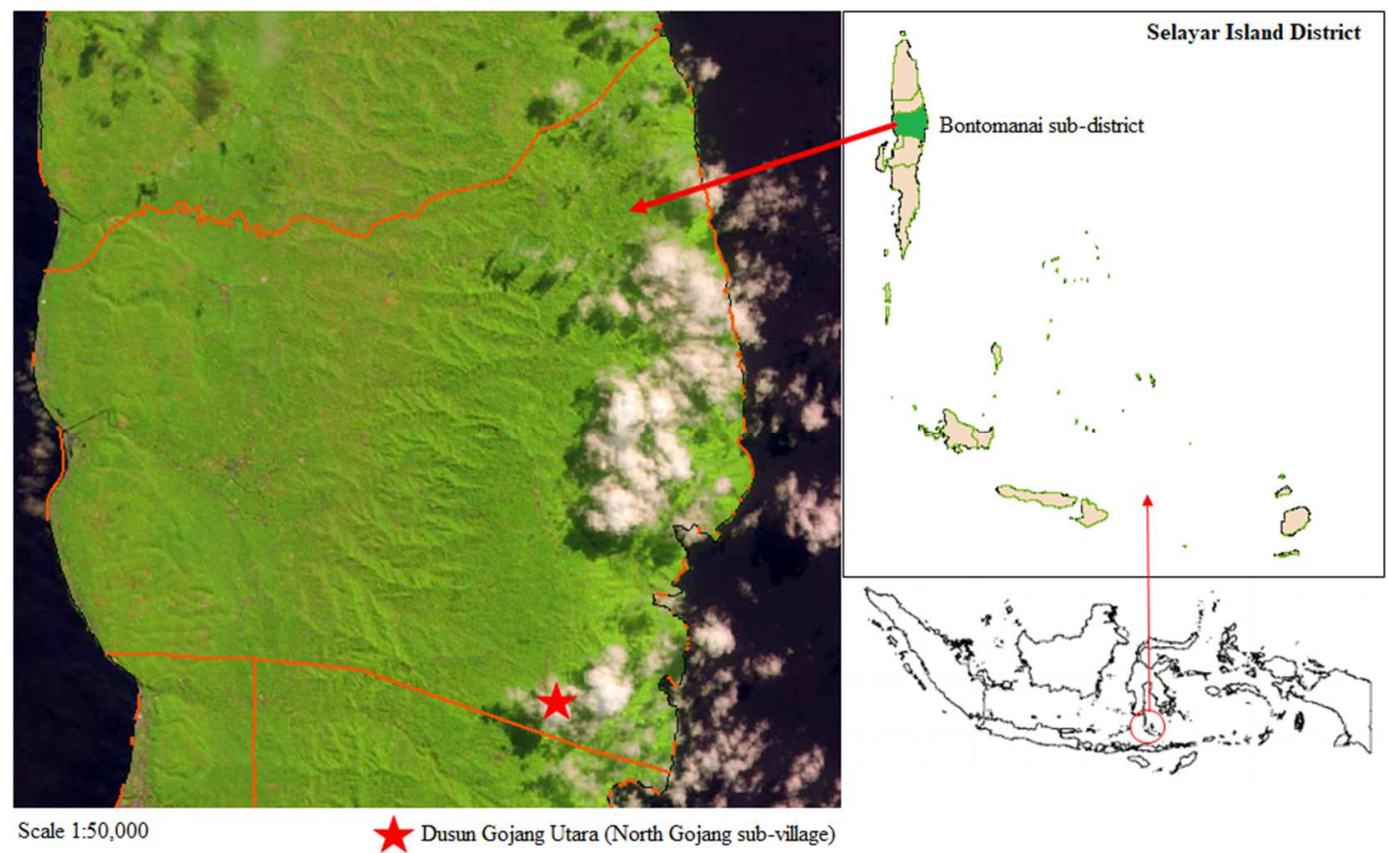

Figure 4. Location of Dusun Gojang Utara

Most of the studies rely on SWOT analysis, and at the moment it was not quite suitable due to the fact that this study searched for both environmental and physical feasibilities that would enable the development of community-based tourism. Instead, the study utilized the guideline from the Ministry of Forestry (2003), which is called as ADO-ODTWA Guideline (Pedoman Analisis Daerah Operasi-Obyek dan Daya Tarik Wisata Alam = Guideline to the analysis of areas for the operation, object and attraction of nature tourism).

Using this guideline, two types of data were collected during the field survey: (a) primary data that were related to the actual village condition and the scoring of potential tourism object or attraction, and (b) secondary data that were mined mainly to gain theoretical background derived from the internet, books, news and 
articles. The scoring of potential tourism object/attraction referred to ADOODTWA Guideline.

The study was done in March 2020 in Dusun Gojang Utara, Bontomarannu Village, Bontomanai Sub-district, Selayar Islands District. A descriptive-status approach was used in this study that was sought to answer questions about real-life situations. Two types of data were collected during the field survey: (a) primary data that were related to the actual village condition and the scoring of potential tourism object or attraction, and (b) secondary data that were mined mainly to gain theoretical background derived from the internet, books, news and articles. The scoring of potential tourism object/attraction utilized the guideline from the Ministry of Forestry (2003), which is called as ADO-ODTWA Guideline (Pedoman Analisis Daerah Operasi-Obyek dan Daya Tarik Wisata Alam = Guideline to the analysis of areas for the operation, object and attraction of nature tourism).

ADO-ODTWA Guideline requires analysis on the following criteria: (1) attractiveness; (2) potential market; (3) accessibility; (4) the condition of surrounding area; (5) management and service potential; (6) climate; (7) accommodation; (8) supporting facilities; (9) clean water availability; (10) relation with other tourism objects in the surrounding area; (11) security; (12) area's carrying capacity; (13) visitor arrangement; (14) market assessment; and (15) marketing assessment. Each criteria has its own elements that need to be assessed in the field, scored independently, and summed up to represent the criteria. The aggregation of score for each criteria uses the following simple equation:

$S=\sum E S i x$ Wi

where,

$S=$ score of the criteria; $E s i=$ the score of element $i$ in the criteria; $W i=$ weight of the score for element $i$, which is given by ADO-ODTWA Guideline.

A complete set of these criteria and their scores are available upon request to the first author.

\section{RESULTS AND DISCUSSION}

\section{Results of Assessment based on ADO-ODTWA Guideline}

\section{a. Attraction}

According to Ginting, Patana, \& Rahmawaty (2013), visitors will come to a location if the location has appeal. Attraction is the main factor that will invite tourists to visit. On the other hand, attractiveness has different interpretations for the tourist's objective or purpose. Domestic travelers (domestic tourists) will have a different interpretation from foreign travelers (foreign tourists). Domestic tourists are generally still at the stage of "enjoying" tourist objects or destinations, while foreign tourists - especially from Europe, the United States, Canada and Australia are already at the "contribution" stage, in the sense of "what can be given to help increase the local welfare".

Unfortunately, this understanding has never been understood by domestic tourism actors, including the government, so it is not surprising that many foreign businessmen have their own "guest houses", "homestays", restaurants, or cafes in 
dusuns, especially in the locations where tourism is already advanced. In general, foreign tourists are looking for something unique, authentic (original) that increase their knowledge and experience. Something that is common for local people is actually a unique experience for foreign tourists. Tourism in Indonesia has not taken advantage of this principle.

The result of the assessment on attractiveness component of Dusun Gojang Utara is presented in the following table.

\section{Table 9. Attractiveness}

\begin{tabular}{|c|c|c|c|c|}
\hline No & Elements & Score & Wieght & $\begin{array}{l}\text { Element } \\
\text { score }\end{array}$ \\
\hline 1 & $\begin{array}{l}\text { The natural beauty: (a) the view towards } \\
\text { dusun is attractive; (b) varied views towards } \\
\text { dusun; (c) Interesting views of dusun area; } \\
\text { and (d) the beauty of the dusun environment }\end{array}$ & 25 & 6 & 150 \\
\hline 2 & $\begin{array}{l}\text { Uniqueness of natural resources: (a) } \\
\text { ecosystem; and (b) daily customs/activities } \\
\text { of the local community }\end{array}$ & 15 & 6 & 90 \\
\hline 3 & 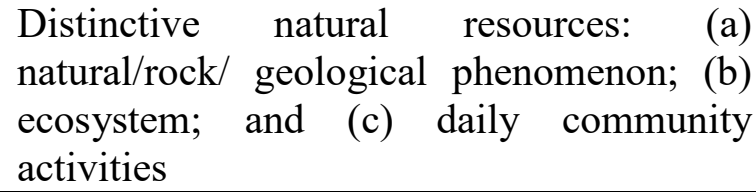 & 20 & 6 & 120 \\
\hline 4 & $\begin{array}{l}\text { Natural resources integrity: (a) natural } \\
\text { phenomenon/rock/geology; (b) ecosystem; } \\
\text { and (c) water }\end{array}$ & 25 & 6 & 150 \\
\hline 5 & $\begin{array}{l}\text { Natural resource sensitivity: } \\
\text { Erosion/landslide; and (b) ecosystem/forest }\end{array}$ & 25 & 6 & 150 \\
\hline 6 & $\begin{array}{l}\text { Potential tourism activities: (a) } \\
\text { amenity/scenery; (b) hiking; (c) tracking; (d) } \\
\text { climbing; (e) camping; (f) nature } \\
\text { conservation education; (g) socio-cultural } \\
\text { education; and (h) daily community } \\
\text { activities }\end{array}$ & 30 & 6 & 180 \\
\hline 7 & $\begin{array}{l}\text { Factors affecting the cleanliness of dusun: } \\
\text { (a) nature; (b) settlements; (c) waste; and (d) } \\
\text { nuisance animals }\end{array}$ & 20 & 6 & 120 \\
\hline 8 & $\begin{array}{l}\text { Regional security: no potential security } \\
\text { disturbance }\end{array}$ & 30 & 6 & 180 \\
\hline & Score of the criteria & & & 1140 \\
\hline
\end{tabular}

Source: Primary data 2020

If the dusun is well organized, the beauty of this area will be even better, especially when the houses are re-built to their traditional style: houses on stilts with bamboo roofs. The most unique element in this dusun lies in the daily activities of the local people who are very dependent on canary nuts. The actual processing of canary nuts has a very unique appeal, and will be able to provide new learning 
and experiences for foreign tourists.

\section{b. Potential market}

The 2003 ADO-ODTWA guideline could not be fully utilized because it was supposed to be assessed based on the potential local market. However, Takabonerate National Park data states that the average tourist who visits the national park to dive is around 700-1000 people per year. By assuming that the maximum number of visitors to the national park per year is only 700 people, such market potential is high for a village tourism. By using a scoring system and the same weighting as the ODTWA 2003 guideline, the market potential value is predicted as follows (Table 3).

Table 10. Potential market

\begin{tabular}{|l|l|l|l|l|}
\hline No & Element & Score & Wieght & $\begin{array}{l}\text { Element } \\
\text { score }\end{array}$ \\
\hline 1 & Potenstial market & 30 & 5 & 150 \\
\hline & Score of the criteria & & & $\mathbf{1 5 0}$ \\
\hline
\end{tabular}

Source: Primary data 2020

\section{c. Accessibility}

Wulan, Albayudi, \& Lidiarti (2019) states that accessibility is an indication of whether an object is easy to reach. They also states that ecotourism does not require easy access because difficult access is actually an attraction for ecotourism. This statement is actually not exactly true, because this statement leads to adventure tourism that demands an adrenaline challenge. In the assessment of accessibility components, the 2003 ADO-ODTWA guidelines could not be fully used because the elements in the guidelines were not in accordance with the conditions of the Selayar Islands District, so that the modifications were made as presented in Table 4.

\section{Table 11. Accessibility}

\begin{tabular}{|l|l|l|l|l|}
\hline No & Elements & Score & Wieght & $\begin{array}{l}\text { Element } \\
\text { score }\end{array}$ \\
\hline 1 & $\begin{array}{l}\text { Road conditions from the district capital to } \\
\text { Dusun Gojang Utara: Very bad }\end{array}$ & 10 & 5 & 50 \\
\hline 2 & $\begin{array}{l}\text { Travel time from Makassar to Selayar: <1 } \\
\text { hour }\end{array}$ & 30 & 5 & 150 \\
\hline 3 & $\begin{array}{l}\text { Travel time from the district capital: 1 hour } \\
\text { (due to very bad road conditions) }\end{array}$ & 30 & 5 & 150 \\
\hline 4 & $\begin{array}{l}\text { Frequency of public transportation from } \\
\text { district capital to dusun (unit/day): None }\end{array}$ & 10 & 5 & 50 \\
\hline & Score of the criteria & & & $\mathbf{4 0 0}$ \\
\hline
\end{tabular}

Source: Primary data 2020

The nearest international airport to the Selayar Islands (Benteng City) is 
Sultan Hasanuddin Airport in Ujungpandang (Makassar), which can be reached in less than 1 hour. Dusun Gojang Utara is located in Bontomarannu Village (Bontomanai sub-district), which is only $14 \mathrm{~km}$ from Benteng City - the district capital. The road condition from Benteng City to the entrance of dusun, which runs through Dusun Gollek, as far as $10 \mathrm{~km}$ is classified as very good, but the road condition toward Dusun Gojang Utara, which is $4 \mathrm{~km}$ away, is classified as very bad. It takes more than 30 minutes to get to the end of the dusun. There are no public vehicle that serves the local community, so almost all residents own a two-wheeled motorized vehicle. Ginting et al. (2013) stated that the factors that make an area attractive to visitors are its proximity, easy access from international airports, and a comfortable trip to tourist destinations. Good accessibility will make tourist locations attractive to visit by various types of transportation (Ernawati, 2010).

\section{d. The condition of surrounding area}

As described in the 2003 ADO-ODTWA Guidelines, the conditions of surrounding area that need to be assessed consist of: the spatial layout of the object area, the unemployment rate of local community, the livelihoods and education level of population, the potential space for visitors to move, the level of soil fertility, natural resources surrounding the area, as well as community responses to tourism development. The results of the assessment are presented in Table 5.

Table 12. Condition of surrounding area

\begin{tabular}{|c|c|c|c|c|}
\hline No & Elements & Score & Wieght & $\begin{array}{l}\text { Element } \\
\text { score }\end{array}$ \\
\hline 1 & $\begin{array}{l}\text { Spatial planning of object area: In } \\
\text { accordance with the district government } \\
\text { plans }\end{array}$ & 5 & 5 & 25 \\
\hline 2 & Unemployment rate: $5-9 \%$ & 20 & 5 & 100 \\
\hline 3 & $\begin{array}{l}\text { Occupation: Almost all residents are } \\
\text { farmers; only } 2 \text { families are elementary } \\
\text { school teachers }\end{array}$ & 20 & 5 & 100 \\
\hline 4 & $\begin{array}{l}\text { Space for visitors: Somewhat limited, only } \\
<30 \text { ha }\end{array}$ & 10 & 5 & 50 \\
\hline 5 & $\begin{array}{l}\text { Education: Mostly of junior high school } \\
\text { graduates }\end{array}$ & 25 & 5 & 125 \\
\hline 6 & Soil fertility: very fertile & 30 & 5 & 150 \\
\hline 7 & Natural resources: very potential for tourism & 30 & 5 & 150 \\
\hline \multirow[t]{2}{*}{8} & $\begin{array}{l}\text { Response to OWA development: Very } \\
\text { supportive }\end{array}$ & 30 & 5 & 150 \\
\hline & Score of the criteria & & & 850 \\
\hline
\end{tabular}

Source: Primary data 2020

The Government of the Selayar Islands Disirict is very supportive of tourism development initiatives in the region. However, based on the Regulation of the Selayar Islands District (Perda) No. 6/2009, the main themes of the Bontomanai District Tourism Destination are "old heritage villages" and "Mesjid Tua (old 
mosque) Gantarang Lala Bata". Unfortunately, this Perda still relies on the potential for historical tourism for Bontomanai District, although in the 2012-2032 Spatial Planning of Selayar District, this sub-district is designated as an agro-tourism area. The Perda and spatial planning documents do not take into account the potential development of various DUTABAKAT ${ }^{1}$, which is quite diverse in Selayar Island.

Most of the local residents are junior high school graduates, and almost all residents have the main livelihood as canary garden farmers, and the unemployment rate can be categorized to be trivial. With an elongated stretch on the embankment of a steep hill and only about $3 \mathrm{~km}$ (from the east to the west end), while the left and right sides are canary gardens on steep hills, this dusun has a rather limited space for visitors (in under $30 \mathrm{ha}$ ). However, the land along this hamlet is very fertile, so that various types of plants can thrive without the need for fertilization. In general, the dusun's natural resources are very potential for the development of plant commodities that can become tourist objects. The local residents are very supportive of the development of DUTABAKAT.

\section{e. $\quad$ Management and service}

For the development of DUTABAKAT targeting foreign tourists, the ability to communicate in foreign languages will be an obstacle, because generally the local residents are only able to speak the local dialect and Bahasa Indonesia. However, the local residents have high potential for visitor service: they are very friendly to guests, able to communicate with guests, and appear to have the ability to provide comfortability to guests visiting the dusun.

\section{Table 13. Management and service}

\begin{tabular}{|l|l|l|l|l|}
\hline No & Elements & Score & Wieght & $\begin{array}{l}\text { Element } \\
\text { score }\end{array}$ \\
\hline 1 & $\begin{array}{l}\text { Language skills: (a) Local dialect; and (b) } \\
\text { Bahasa Indonesia }\end{array}$ & 15 & 4 & 60 \\
\hline 2 & $\begin{array}{l}\text { Potential capacity to service guest (visitors): } \\
\text { (a) hospitality; (b) ability; and (c) } \\
\text { communication skills }\end{array}$ & 20 & 4 & 80 \\
\hline Score of the criterias & & & $\mathbf{1 4 0}$ \\
\hline
\end{tabular}

Source: Primary data 2020

\section{f. Climate}

In general, the rainy season on Selayar Island occurs from November to June, and the dry season from August to September. Usually, the occurring rainfall is quite high and is greatly influenced by seasonal winds. The highest number of rainy days is 18 days, which usually occur in February, March and December. The air temperature is $20-31{ }^{\circ} \mathrm{Celsius}$ with an air humidity of $70-95$ percent. The climate conditions in Dusun Gojang Utara are almost the same as the climatic conditions of

${ }^{1}$ DUTABAKAT is an abbreviation in Bahasa Indonesia, which stands for Dusun Wisata Berbasis Masyarakat (Community-based Village Tourism) 
the island.

\section{Table 14. Climate}

\begin{tabular}{|l|l|l|l|l|}
\hline No & Elements & Score & Wieght & $\begin{array}{l}\text { Element } \\
\text { score }\end{array}$ \\
\hline 1 & $\begin{array}{l}\text { Effect of climate on length of visit: } 4-6 \\
\text { months }\end{array}$ & 20 & 4 & 80 \\
\hline 2 & The temperature in the dry season: 28-30oC & 15 & 4 & 60 \\
\hline 3 & Average dry months per year: 4 months & 5 & 4 & 20 \\
\hline 4 & Average humidity per year: $60-65 \%$ & 20 & 4 & 80 \\
\hline & Score of the criteria & & & $\mathbf{2 4 0}$ \\
\hline
\end{tabular}

Source: Primary data 2020

The elements that could become the obstacles in the future are the number of dry months in a year, as well as the combination of air temperature and high humidity. Tourists will usually feel comfortable when the visit is not raining, with air that does not make them sweat profusely.

\section{g. Accommodation}

The accommodation assessment could not be carried out because there has not been any form of lodging built in the dusun.

\section{h. Supporting facility and infrastructure}

The 2003 ADO-ODTWA guideline could not be fully used because the subelements in the guideline do not match the availability of facilities in Dusun Gojang Utara, so the following modification is made.

\section{Table 15. Supporting facility and infrastructure}

\begin{tabular}{|l|l|l|l|l|}
\hline No & Element & Score & Wieght & $\begin{array}{l}\text { Element } \\
\text { score }\end{array}$ \\
\hline 1 & $\begin{array}{l}\text { Infrastructure: (a) road; (b) bridge; (c) } \\
\text { electricity network }\end{array}$ & 25 & 3 & 75 \\
\hline Score of the criteria & & & $\mathbf{7 5}$ \\
\hline
\end{tabular}

Source: Primary data 2020

The available infrastructure is a road network - although it was badly damaged, a sturdy bridge along the road, and a power electricity grid. Telecommunication networks still have to be built to facilitate communication for travelers to Dusun Gojang Utara.

\section{i. $\quad$ Clean water availability}

Clean water comes from springs available throughout the year in abundant volume, and the location of clean water from dusun is closed. There has been water pipelime to more than $50 \%$ of the houses of local residents. However, the water is 
not suitable for direct consumption, and needs to be boiled. At this time, drinking and cooking water needs are obtained by buying "gallon water" which is sold daily by traders from Benteng City.

\section{Table 16. Clean water availability}

\begin{tabular}{|l|l|l|l|l|}
\hline No & Elements & Score & Wieght & $\begin{array}{l}\text { Element } \\
\text { score }\end{array}$ \\
\hline 1 & Volume: abundant & 22.5 & 6 & 135 \\
\hline 2 & Distance to dusun: 0-1 km & 30 & 6 & 180 \\
\hline 3 & Pipelining: Easy & 22.5 & 6 & 135 \\
\hline 4 & Feasible to consume: needs simple treatment & 22.5 & 6 & 135 \\
\hline 5 & Availability: throughout the year & 30 & 6 & 180 \\
\hline & Score of the criteria & & & $\mathbf{7 6 5}$ \\
\hline
\end{tabular}

Source: Primary data 2020

\section{j. $\quad$ Relation to other tourism objects on the island}

The 2003 ADO-ODTWA guideline could not be fully used because the subelements in the guideline do not match the conditions of Selayar Islands District, so the following modification is made.

Table 17. Relation to other tourism objects on the island

\begin{tabular}{|l|l|l|l|l|}
\hline No & Elements & Score & Wieght & $\begin{array}{l}\text { Element } \\
\text { score }\end{array}$ \\
\hline 1 & Similar tourism object: not available & 30 & 1 & 30 \\
\hline 2 & Different tourism object: $>4$ & 30 & 1 & 30 \\
\hline & Score of the criteria & & & $\mathbf{6 0}$ \\
\hline
\end{tabular}

Source: Primary data 2020

Community-based tourism objects (or DUTABAKAT) do not yet exist in this district. This makes sense because the Government of Indonesia does not yet really understand the potential of DUTABAKAT. Only in 2018, the Government of Indonesia cq. The Ministry of Tourism understands that community-based tourism is much more resilient when the tourism industry is experiencing a sluggishness. This is due to the fact that with DUTABAKAT, people do not rely their income on tourism, because their main income is their daily livelihoods which are used as tourist objects. Income from tourism activities is only an additional income.

\section{k. Security}

The 2003 ADO-ODTWA guideline could not be fully used because the subelements in the guideline do not match the conditions of Selayar Islands District, so the following modification is made. 


\begin{tabular}{|l|l|l|l|l|}
\hline No & Elements & Score & Wieght & $\begin{array}{l}\text { Element } \\
\text { score }\end{array}$ \\
\hline 1 & Security disturbance: None & 30 & 5 & 150 \\
\hline 2 & $\begin{array}{l}\text { Fire (based on the drivers): natural } \\
\text { (lightning) }\end{array}$ & 30 & 5 & 150 \\
\hline 3 & Tree cutting: personal use & 30 & 5 & 150 \\
\hline 4 & Land use: settlement & 30 & 5 & 150 \\
\hline & Score of the criteria & & & $\mathbf{6 0 0}$ \\
\hline
\end{tabular}

Source: Primary data 2020

Local residents stated that there has never been any security disturbance in the dusun. Land/forest fires also never occur, and if they do, the cause is natural. For example, lightning that burns a tall tree. Tree cutting is only carried out for personal needs, for example, to produce their own building materials. But the trees used as building materials in this dusun are generally coconut trees. The land along the hamlet road is used for residential areas.

\section{l. Carrying capacity}

The 2003 ADO-ODTWA guideline could not be fully used because the subelements in the guideline do not match the condition of Dusun Gojang Utara, so the following modification is made.

\section{Table 19. Carrying capacity}

\begin{tabular}{|l|l|l|l|l|}
\hline No & Elements & Score & Wieght & $\begin{array}{l}\text { Element } \\
\text { score }\end{array}$ \\
\hline 1 & $\begin{array}{l}\text { Ability to accommodate visitors } \\
\text { (people/day): maximum 90 people/day (the } \\
\text { number of houses is only 97) }\end{array}$ & 25 & 3 & 75 \\
\hline 2 & Soil sensitivity to erosion: Moderate & 20 & 3 & 60 \\
\hline 3 & Slope factor: 10-15\% & 25 & 3 & 75 \\
\hline 4 & Additional activity: research & 30 & 3 & 90 \\
\hline & Score of the criteria & & & $\mathbf{3 0 0}$ \\
\hline
\end{tabular}

Source: Primary data 2020

The capacity of Dusun Gojang Utara to accommodate visitors (person/day) is quite limited. With only 97 houses, the maximum number of visitors that can be accommodated is only 90 people/day. With steep hills, with a $10-15 \%$ slope, the soil condition is considered to be moderately sensitive to erosion. Additional activities that can be carried out in here are research, especially regarding canary forests as a man-made ecosystem, or other research related to canary nuts.

\section{m. Visitor Settings}

Assessment of visitor arrangements could not be carried out, because the dusun has not become a tourist destination. 


\section{n. Marketing}

Assessment of marketing could not be carried out, because the dusun has not become a tourist destination.

\section{o. Market Share Assessment}

Assessment of market share could not be carried out, because it has not become a tourist destination.

The minimum and maximum values for each criteria were established, and three classes of potencies were constructed: high, medium, and low, based on the interval values. The classifications are presented in Table 13.

Table 20. The potential of Dusun Gojang Utara as DUTABAKAT

\begin{tabular}{|c|c|c|c|c|c|}
\hline \multirow[b]{2}{*}{ Criteria } & \multicolumn{3}{|l|}{ Score of } & \multirow{2}{*}{$\begin{array}{l}\text { Total } \\
\text { score of } \\
\text { criteria }\end{array}$} & \multirow{2}{*}{$\begin{array}{l}\text { Potential } \\
\text { category }\end{array}$} \\
\hline & $\begin{array}{l}\text { High } \\
\text { potency }\end{array}$ & $\begin{array}{l}\text { Moderate } \\
\text { potency }\end{array}$ & $\begin{array}{l}\text { Low } \\
\text { potency }\end{array}$ & & \\
\hline Attraction & $\begin{array}{l}1042 \\
1440\end{array}$ & $641-1041$ & $240-640$ & 1140 & High \\
\hline Potential market & $60-100$ & $101-140$ & $141-180$ & 180 & High \\
\hline Accessibility & $467-600$ & $333-466$ & $200-332$ & 400 & Moderate \\
\hline $\begin{array}{l}\text { The condition of } \\
\text { surrounding } \\
\text { area }\end{array}$ & $\begin{array}{l}934 \\
1200\end{array}$ & $667-933$ & $400-666$ & 850 & Moderate \\
\hline $\begin{array}{l}\text { Management } \\
\text { and service }\end{array}$ & $188-240$ & $134-187$ & $80-133$ & 140 & Moderate \\
\hline Climate & $374-480$ & $267-373$ & $160-266$ & 240 & Low \\
\hline Accommodation & $\mathrm{N} / \mathrm{A}$ & & & & \\
\hline $\begin{array}{l}\text { Supporting } \\
\text { facility and } \\
\text { infrastructure }\end{array}$ & $71-90$ & $51-70$ & $30-50$ & 75 & High \\
\hline $\begin{array}{l}\text { Clean water } \\
\text { availability }\end{array}$ & $702-900$ & $501-701$ & $300-500$ & 765 & High \\
\hline $\begin{array}{l}\text { Relation to other } \\
\text { tourism objects } \\
\text { on the island }\end{array}$ & $44-60$ & $27-43$ & $10-26$ & 60 & High \\
\hline Security & $468-600$ & $334-467$ & $200-333$ & 600 & High \\
\hline $\begin{array}{l}\text { Carrying } \\
\text { capacity }\end{array}$ & $281-360$ & $201-280$ & $120-200$ & 300 & High \\
\hline Visitor Settings & $\mathrm{N} / \mathrm{A}$ & & & & \\
\hline Marketing & N/A & & & & \\
\hline $\begin{array}{l}\text { Market Share } \\
\text { Assessment }\end{array}$ & N/A & & & & \\
\hline All criteria & $\begin{array}{l}4702 \\
6150 \\
\end{array}$ & $\begin{array}{l}3251 \\
4701 \\
\end{array}$ & $\begin{array}{l}1800 \\
3250\end{array}$ & 4750 & High \\
\hline
\end{tabular}


Overall, Dusun Gojang Utara has a high potency as a community-based tourism destination, although there are four criteria that have medium and low potential, namely: accessibility (moderate), surrounding conditions (moderate), management and services (moderate), and climate (low). The climatic element cannot be changed in any way, but comfortability can be created to mitigate climatic conditions, for example the architecture of a house packed into a traditional one, or the provision of umbrellas in each house for guests traveling to the dusun. Other elements do indeed require intervention from the local government and collaboration with investors in social enterprises. Once these intervention take place, the local economy could certainly revitalized through a community-based tourism.

\section{Overlooked Potential Natural Resource}

Indonesian canary nuts are less well-known than similar nuts from other countries, such as India, the Middle East, America and even Europe, even though Indonesian canary nuts have the potential as a source of food and medicine (Amini 2018; Rahman, Anggadiredja, Gusdinar, Sitompul, \& Ryadin, 2019). Within the Selayar Islands Regency area, canary trees are spread across 5 (five) districts with a total area of 351.60 ha, with a production of 299.56 tons from a total of 35,160 trees in 2018. The sub-districts with the largest area of walnut trees are Bontomanai ( area $=178.1$ ha, annual production $=169.58$ tonnes $)$, followed by Buki District (area $=91$ ha, annual production $=68.89$ tonnes $)$, Bontomatane (area $=41$ ha, annual production $=23.22$ tonnes $)$, Bontoharu ( area $=22.5$ ha, annual production $=$ 19.76 tonnes), and Bontosikuyu (area $=19 \mathrm{ha}$, annual production $=18.11$ tonnes) (BPS Selayar Islands, 2019).

Within the Sub-district of Bontomanai, the canary nut area is spread across 9 (nine) villages, and the village with the largest canary nut tree area is Bontomarannu Village (55.5 ha), followed by Bontokoraang (30.5 ha), Bonea Makmur (30 ha), Polebunging (22 ha), Barugaiya (21 ha), East Bonea (13 ha), Parak (2.1 ha), Jambuiya (2 ha), and Mare-Mare (2 ha). The canary forest (garden) in the area of Bontomarannu Village has been targeted by the local government for tourism development.

Of the five dusuns in Bontomarannu Village, Dusun Gojang Utara is the only hamlet where the entire population depends on the management of the canary nut forest and the processing of canary nuts. Average daily income is around Rp. 70,000 per household per day, or about $1 \mathrm{~kg}$ of ready-to-sell canary nuts (at a price of Rp. 70,000 per $\mathrm{kg}$ ). The total population of this dusun is around 420 people, groupped into 130 households, and there are only 97 houses in the area. This dusun is located along a steep hill, where the right and left sides of dusun are covered with canary trees, forming an intact canary forest. Based on its history, the canary forest in this village has existed since the Dutch colonial era, and based on the diameter of the trunk, there are indeed many canary trees of hundreds of years old.

The distance from the district capital - Kota Benteng - to this dusun is only about $14 \mathrm{~km}$, although the road conditions could be classified as very damaged. The road conditions are smooth only from Benteng City to the dusun entry point, which is about $10 \mathrm{Km}$. The journey from Benteng City to the entry point can only be taken 
for about 10 minutes, but from the entrance to the end of Dusun Gojang Utara, it took more than 30 minutes because the road was in very bad condition. Electricity facility is already supplied by the state electriciy company (PLN); clean water sourced from springs is always available throughout the year (although it still needs to be checked for conformity with the quality of daily needs), but communication facilities are still not available.

The canary forest that stretches out along the sides of the road leading to the dusun, all residents who depend on canary nuts, and a short distance from the district capital make Dusun Gojang Utara have great potential for tourism development.

With the concept of "community-based tourism" and from the point of view of foreign tourists, the daily activities of dusun residents in managing canary forest and processing canary nuts have high appeal, which can provide knowledge of rural lifestyles, management of man-made ecosystems, and processing walnut seeds. This high attractiveness will be further enhanced if the spatial planning of dusun is improved, for example by replacing a concrete house with a beautiful traditional stilt house with a bamboo roof. This concept is in accordance with the type of tourists conveyed by Suansri (2003), namely: (a) tourists seeking new experiences, and (b) tourists seeking to learn and support environmental conservation and local communities. Under the scheme of community-based tourism in this "dusun", here are the activities in which the tourists can participate (see Supplementary Figure):

1. Learn how to make traditional basket from coconut leaves for collecting walnuts

2. Observe how the local people climb the trees to harvest the walnut seeds

3. Involve in collecting walnut seed fallen on the ground

4. Help the local carry the walnut seeds in the traditional baskets; the locals will usually carry the seed collection of large quantities.

5. Help the locals prepare the soaking process

6. Help the locals prepare drying process

7. Learn how to break the hard shell of walnut seeds

8. Learn how to peel off the soft epidermis

9. Participate in preparing the local snacks and cake from walnut seed

10. At convenient time, track the "Kenari Forest".

Tourists can interact with local residents to make woven coconut leaf baskets to collect walnuts or traditional hat weaving, and participate in harvesting and collecting canary nuts. The most interesting activity is how to open canary nuts, and the tourists can try this traditional method. It is indeed necessary to consider the use of other tools, apart from machetes/sharp machetes, because these tools might endanger inexperienced travelers. They can also participate in peeling walnut husks, and making traditional snacks. All these processes are unique experiences for foreign travelers.

\section{CONCLUSION}

As a "community-based tourism" with a target market of foreign tourists, the 
traditional ways of local residents in managing canary gardens as an ecosystem and processing canary nuts (see Supplementary Figure) are an attraction with high authenticity and uniqueness. Thus, Dusun Gojang Utara has the potential to become a "community-based tourism village" or DUTABAKAT.

However, some elements and/or criteria still need to be improved so that this potential becomes more perfect. These elements are: climate, accessibility, telecommunications networks, conditions around the area, as well as management and services. As explained above, the climatic element cannot be changed in any way, but comfortability can be created to cope with climatic conditions, for example the houses are re-built to traditional bamboo-roofed architecture, and supplies of umbrellas in each house for guests traveling to the dusun. Although the distance from the district capital is very close, the condition of the access road to dusun is very bad. This poor road may also cause the absence of public passenger vehicle, but the public passenger vehicles on Selayar Island are indeed very rare.

Telecommunication network is very vital for a village tourism, where the experiences of foreign tourists can be directly informed (or shared) online to colleagues/relatives. This condition is necessary as part of the tourism marketing. On the other hand, the local residents do not have the ability to communicate in foreign languages, even though they are very friendly and have high enthusiasm in communicating with guests from outside their territory. It is true that dusun residents do not need to be proficient in foreign languages either, but a 'tour guide' or 'tour interpreter' can be provided by graduates of the Tourism Polytechnic in Selayar Island.

Dusun Gojang Utara as a tourist village has not seemed to be the priority of the local government, therefore it is not included in the district spatial planning. Indeed, as part of the Bontomarannu Village, this dusun is included as an agrotourism development area, but the potential of this dusun is not for agro-tourism. On the other hand, this hamlet has limited space for visitors, so the development of DUTABAKAT Gojang Utara in the future will require visitor management. For example, by limiting the number of visits per day. In terms of the tourism industry, limiting the number of visitors will actually increase market value.

\section{AUTHOR CONTRIBUTIONS}

ASA initiated the conceptual framework, followed by the research design and article writing. $\mathrm{N}$ and $\mathrm{S}$ undertook initial surveys, followed by discussion for writing the article. HSS contributed the community-based-tourism aspect analysis. JS supervised and copy-edited on the article. AR assisted the field surveys and observations during the study. All authors have contributed to design the research surveys, analyze, and discuss the results.

\section{FUNDING}

This study was funded in part from the Global Challenge Research Fund (GCRF) UK via the delivery partner Research and Innovation (UKRI) under grant agreement reference NE/P021107/1 to the Blue Communities project. 


\section{ACKNOWLEDGMENTS}

The authors are very grateful for the supports from the District Government of Selayar Islands, and the cheerful communities of Dusun Gojang Utara.

\section{REFERENCES}

Amini, R. (2018). Kandungan kalsium dan protein pada susu kenari. Monografi Laboratorium Dasar Fisika-Kimia Universitas Muhammadiyah Maluku Utara.

Balai Taman Nasional Taka Bonerate. (2018). Survey Lokasi Dan Diskusi Pengembangan Ekowisata Hutan Kenari Di Dusun Gojang Utara. Retrieved from https://tntakabonerate.com/id/survey-lokasi-dan-diskusipengembangan-ekowisata-hutan-kenari-di-dusun-gojang-utara/

Disbudpar-Sulsel (Dinas Kebudayaan dan Kepariwisataan Provinsi Sulawesi Selatan). (2018). Laporan Kinerja Instansi Pemerintah (LKIP) Tahun Anggaran 2017. Makassar.

Ernawati, N. M. (2010). Tingkat Kesiapan Desa Tihingan-Klungkung, Bali Sebagai Tempat Wisata Berbasis Masyarakat. Jurnal Analisis Pariwisata, 10(1), 1-8.

Ferdiansyah, A. (2019). Komunikasi Pemasaran Pariwisata di Provinsi Sulawesi Selatan (Studi Kasus: Bidang Pengembangan Pemasaran Dinas Kebudayaan Dan Kepariwisataan Provinsi Sulawesi Selatan). Skripsi. Program Strata I, Program Studi Industri Perjalanan, Sekolah Tinggi Pariwisata NHI, Bandung.

Ginting, I. A., Patana, P., \& Rahmawaty, R. (2013). Penilaian dan Pengembangan Potensi Objek dan Daya Tarik Wisata Alam di Taman Wisata Alam (TWA) Sibolangit (Assessment and Development of Object Potency and Pull Factor of Ecotourism at Sibolangit Recreational Park). Peronema Forestry Science Journal, 2(1), 74-81.

KKUKM (Kementerian Koperasi dan Usaha Kecil dan Menengah). (2015). Buku Panduan Pengembangan Desa Wisata Hijau. Diterbitkan oleh Asisten Deputi Urusan Ketenagalistrikan dan Aneka Usaha, Kementerian Koperasi dan UKM Republik Indonesia, dengan dukungan dari GIZ, bekerjasama dengan BAPPENAS, Kementerian Pariwisata,. Jakarta: Kementerian Pariwisata dan Ekonomi Kreatif.

LPEM-FEBUI. (2018). Laporan Akhir Kajian Awal Dampak Sektor Pariwisata Terhadap Perekonomian Indonesia. Jakarta, 10 Oktober 2018. 142 pp. Jakarta: LPEM-FEBUI (Lembaga Penyelidikan Ekonomi dan Masyarakat Fakultas Ekonomi dan Bisnis Universitas Indonesia).

Ministry of Forestry Indonesia. (2003). Pedoman Analisis Daerah Operasi Objek dan Daya Tarik Wisata Alam (ADO-OTWA). Bogor: Direktorat Jenderal Perlindungan Hutan dan Pelestarian Alam, Direktorat Wisata Alam dan Pemanfaatan Jasa Lingkungan.

Neumeier, S., \& Pollermann, K. (2014). Rural tourism as promoter of rural development-Prospects and limitations: Case study findings from a pilot projectpromoting village tourism. European Countryside, 6(4), 270.

Poerwanto, E. (2020). Indonesia Tak Serius Hadapi Pergeseran Paradigma 
Pariwisata Dunia. Retrieved from https://bisniswisata.co.id/indonesia-takserius-hadapi-pergeseran-paradigma-pariwisata-dunia/

Purbasari, N., \& Asnawi, A. (2014). Keberhasilan Community Based Tourism di Desa Wisata Kembangarum, Pentingsari, dan Nglanggeran. Jurnal Teknik Perencanaan Wilayah Kota, 3(3), 476-485.

Rahman, H., Anggadiredja, K., Gusdinar, T., Sitompul, J. P., \& Ryadin, A. R. (2019). Kajian komposisi kimia, nilai nutrisi, dan etnofarmakologis tanaman genus kenari. Jurnal Fitofarmaka Indonesia, 6(1), 325-333.

Salmiah, N. (2019). Pengembangan Potensi Wisata Desa Buluhcina Kabupaten Kampar. Jurnal Bakti Saintek: Jurnal Pengabdian Masyarakat Bidang Sains Dan Teknologi, 3(1), 11-21.

Sekartjakrarini, S., Bernanto, E., Laksana, B. K. ., \& Wahyudi, M. (2015). Feasibility Study on Village Ecotourism Development at Tekelan, Betung Kerihun National Park - Indonesia. ITTO PD 617/11 (F) Rev. 4.

Sjamsu, A. S., \& Dahrma, I. M. K. A. (2018). Studi Kelayakan Potensi Pengembangan Desa Wisata Di Kawasan Pulau Saponda Dalam Kabupaten Konawe. Seminar Nasional Teknologi Terapan Berbasis Kearifan Lokal (SNT2BKL).

Suansri, P. (2003). Community Based Tourism Handbook. Responsible Ecological Social Tour-REST Project, 120.

Suyono, H. (2019). Nusantara Village Tourism Festval in Jakarta. Retrieved August 8, 2020, from https://gemari.id/gemari/2019/8/17/nusantara-village-tourismfestval-in-jakarta

Tang, L. (2017). The Overview of the Origin and Research of Rural Tourism Development. 7th International Conference on Management, Education, Information and Control (MEICI 2017) Vol. 156, 448-452. Atlantis Press.

Wulan, C., Albayudi, A., \& Lidiarti, T. (2019). Analysis of Potential Ecotourism in the Rawa Bento, Kerinci District. Jurnal Silva Tropika, 3(1), 95-107.

Yakup, A. P. (2019). Pengaruh Sektor Pariwisata Terhadap Pertumbuhan Ekonomi Di Indonesia. Tesis Magister Sains Ekonomi (MSE). Program Studi Magister Ilmu Ekonomi, Departemen Ilmu Ekonomi, Fakultas Ekonomi Dan Bisnis, Universitas Airlangga. 


\section{SUPPLEMENTARY FIGURE}

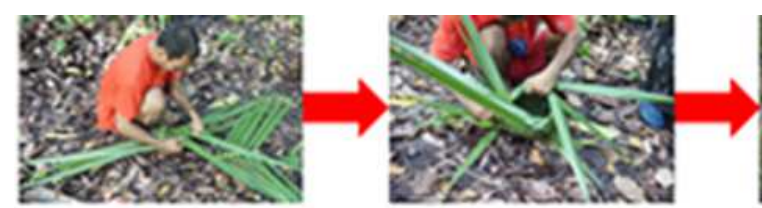

1

1
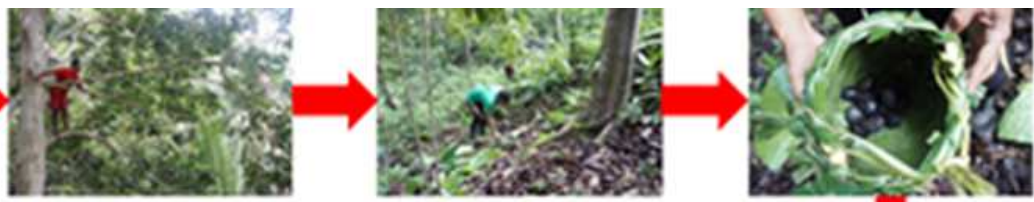

2

3
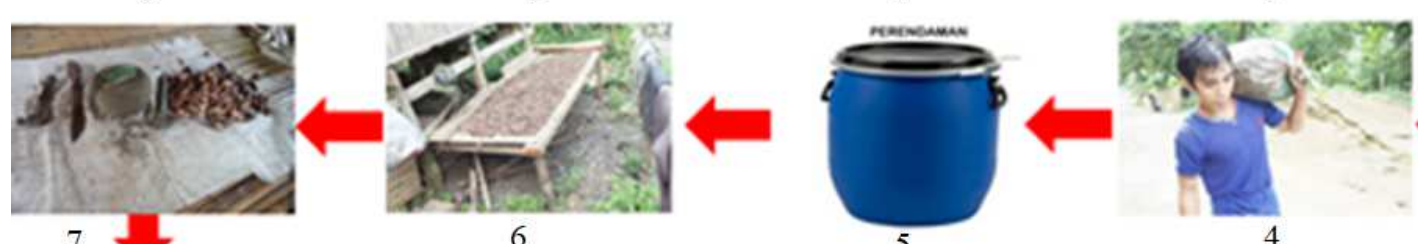

4

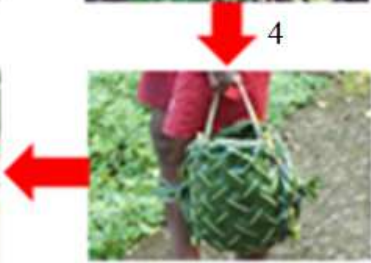

6

4
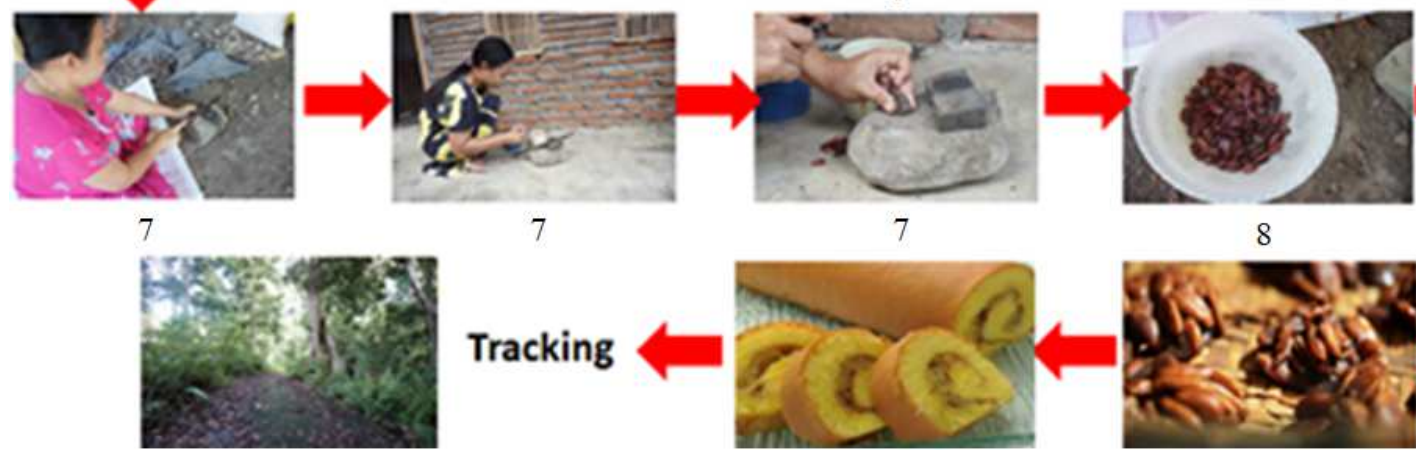

7

8

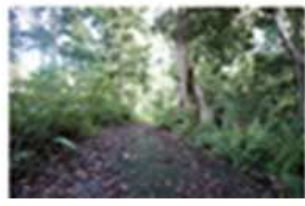

10
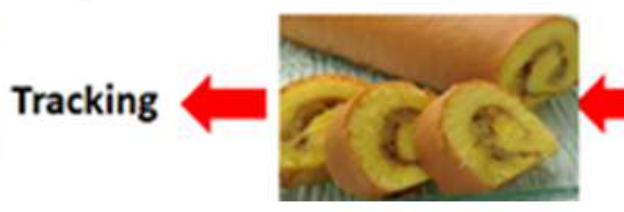

9

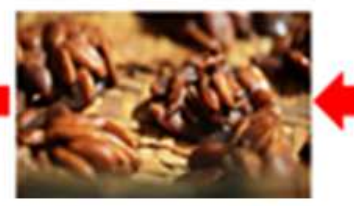

9

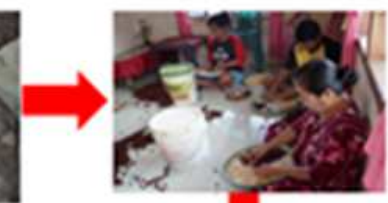

\section{Notes:}

1. Learn how to make traditional basket from coconut leaves for collecting walnuts

2. Observe how the local people climb the trees to harvest the walnut seeds

3. Involve in collecting walnut seed fallen on the ground

4. Help the local carry the walnut seeds in the traditional baskets; the locals will usually carry the seed collection of large quantities.

5. Help the locals prepare the soaking process

6. Help the locals prepare drying process

7. Learn how to break the hard shell of walnut seeds

8. Learn how to peel off the soft epidermis

9. Participate in preparing the local snacks and cake from walnut seed

10. At convenient time, track the "Kenari Forest". 